\title{
CNS inflammatory vasculopathy with antimyelin oligodendrocyte glycoprotein antibodies in COVID-19
}

Ashwin A. Pinto, DPhil, FRCP, Liam S. Carroll, PhD, MRCP, Vijay Nar, MRCP, Aravinthan Varatharaj, MRCP, and Ian Galea, PhD, FRCP

Neurol Neuroimmunol Neuroinflamm 2020;7:e813. doi:10.1212/NXI.0000000000000813

A 44-year-old right-handed woman reported a gradual onset of right hand incoordination seven days after the onset of minor respiratory symptoms and pruritus due to COVID-19 infection. Over 48 hours, the patient developed word-finding difficulties and progression in right arm weakness leading to presentation to the emergency department as a suspected stroke.

Neurologic examination confirmed a mild expressive and receptive dysphasia, visual and sensory inattention, and Medical Research Council grade 4/5 weakness in the right arm and right leg. There was a rash on the chest wall bilaterally but no abnormal respiratory findings.

Blood workup confirmed normal results for full blood count (lymphocytes $1.5 \times 10^{9} / \mathrm{L}$ ), C-reactive protein, lactate dehydrogenase, and ferritin. In addition, the blood tests for antinuclear antibody, antineutrophil cytoplasmic antibody, anticardiolipin immunoglobulin G and immunoglobulin $\mathrm{M}$, lupus anticoagulant and cold agglutinins were negative. The HIV and syphilis serologies were also negative. Severe acute respiratory syndrome coronavirus 2 (SARS-CoV-2) PCR from nasopharyngeal swab was positive.

MRI of the head with gadolinium and magnetic resonance angiography at presentation showed T2-hyperintensity within the centrum semiovale bilaterally in a periventricular location, extending along the left temporal and occipital horns and into the subcortical deep white matter bilaterally, more extensive in the left hemisphere. There was perivascular enhancement within the lesions, although no diffusion restriction, hemorrhage, or mass effect was found, and magnetic resonance angiography was normal (figure, A and D). MRI scan of the spinal cord was unremarkable with no radiologic signs of myelitis. CT of the chest, abdomen, and pelvis was normal with no evidence of pulmonary COVID-19 involvement.

CSF analysis showed $13 / \mathrm{mm}^{3}$ white cells (all mononuclear), red cells $<1$, protein $507 \mathrm{mg} / \mathrm{L}$, glucose $2.9 \mathrm{mmol} / \mathrm{L}$ (serum glucose $6.3 \mathrm{mmol} / \mathrm{L}$ ) with negative PCR for SARS-CoV-2, herpes simplex types 1 and 2, and JC virus. Oligoclonal bands were absent in the CSF. Although of potential relevance, serum and CSF cytokine analysis was unavailable for practical reasons during the university restrictions on activity in the laboratory.

There was clinical deterioration over the next 6 days with the development of severe aphasia and no antigravity movements of the right upper limb or at the right hip and knee. Repeat MRI brain scan, 6 days after presentation, showed progression of the bilateral centrum semiovale and white matter changes with extension into both hemispheres and more pronounced perivascular enhancement (figure, B and E). There were multiple, new cystic spaces without CSF signal consistent with enlarged perivascular spaces. Repeat CSF analysis on day 6 showed 8 mononuclear cells only and negative repeat SARS-CoV-2 PCR.

\author{
Correspondence \\ Dr. Pinto \\ Ashwin.Pinto@nhs.net
}

MORE ONLINE

COVID-19 Resources

For the latest articles, invited commentaries, and blogs from physicians around the world

NPub.org/COVID19

\footnotetext{
From the Wessex Neurological Centre (A.A.P., L.S.C., V.N., A.V., I.G.), Southampton General Hospital, Southampton, UK; and Clinical Neurosciences (A.A.P., A.V., I.G.), Clinical and Experimental Sciences, Faculty of Medicine, University of Southampton, UK.

Go to Neurology.org/NN for full disclosures. Funding information is provided at the end of the article.

The Article Processing Charge was funded by the MRC (UKRI).

This is an open access article distributed under the terms of the Creative Commons Attribution License 4.0 (CC BY), which permits unrestricted use, distribution, and reproduction in any medium, provided the original work is properly cited.
} 

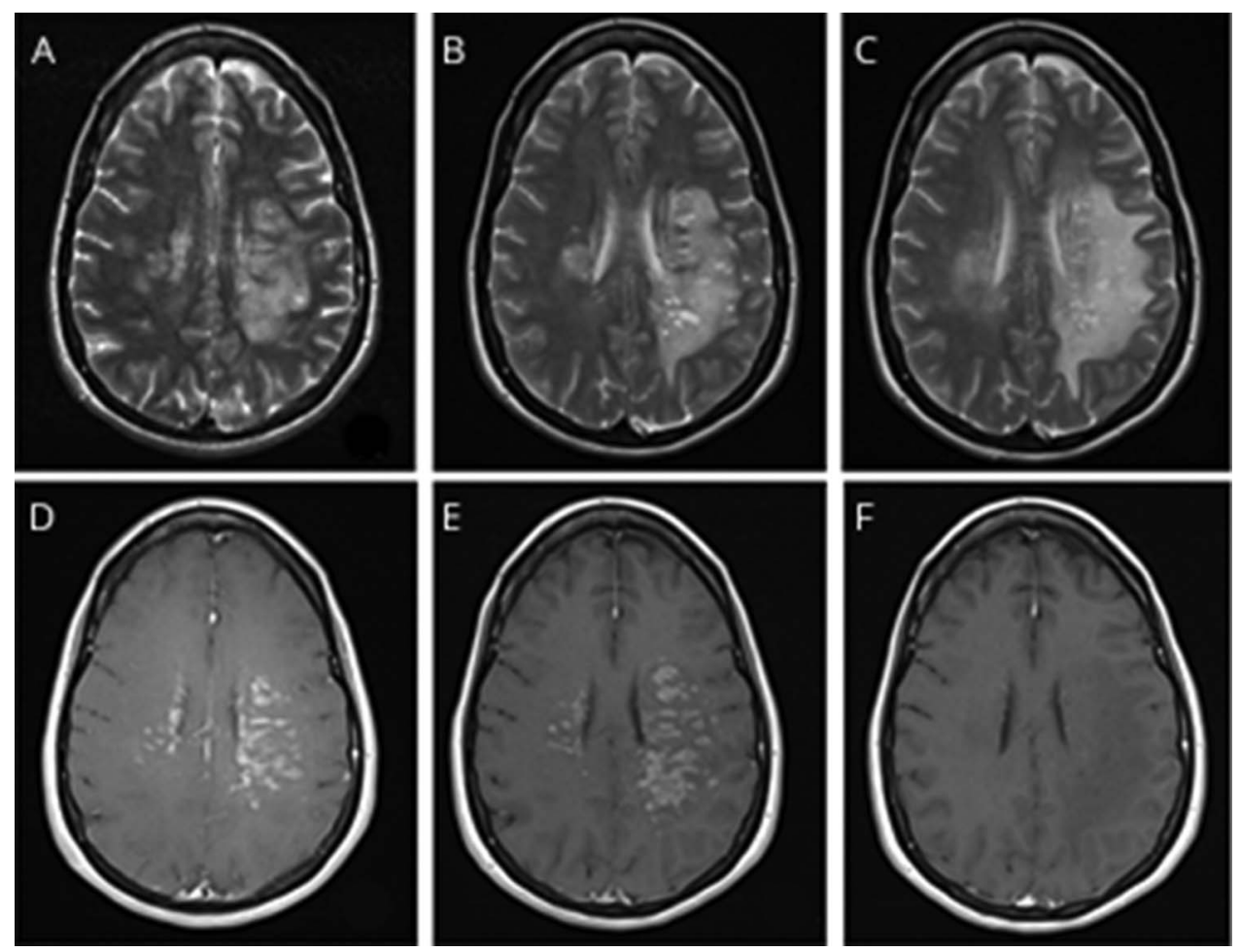

T2-weighted axial images at day 1 (A), day 6 (B), and post-treatment day 17

(C). Postcontrast axial images at day 1

(D), day $6(\mathrm{E})$, and post-treatment day $17(\mathrm{~F})$.

Treatment was initiated at day 6 with IV methylprednisolone (IVMP) $1 \mathrm{~g}$ daily for 5 consecutive days, followed by oral prednisolone $60 \mathrm{mg}$ daily. The patient did not receive experimental antiviral treatment of COVID-19. On day 8, plasma exchange (PLEX) at $3.5 \mathrm{~L} / \mathrm{d}$ (1.5 plasma volumes) was commenced. There was a rapid clinical improvement in the neurologic deficit after the patient started immunomodulatory treatment. The patient had normal speech, almost full power in the right arm and leg, and no visual or sensory inattention at day 18 after 5 sessions of plasma exchange and IVMP. The MRI of the brain scan, after PLEX treatment on day 17 (figure, $\mathrm{C}$ and $\mathrm{F}$ ), showed residual white matter vasogenic edema but no evidence of residual perivascular contrast-enhanced changes. Two weeks after discharge from hospital, an antimyelin oligodendrocyte glycoprotein (MOG) antibody test requested on admission was reported as positive.

Several classic autoimmune neurologic sequelae following COVID-19 have been described to date. ${ }^{1}$ However, this case was unusual for classic anti-MOG disease for a number of reasons. When solitary brain involvement occurs in the absence of opticospinal disease, the clinical and radiologic presentation is usually similar to that of acute disseminated encephalomyelitis, ${ }^{2}$ unlike here. In addition, perivascular enhancement is exceedingly rare in anti-MOG syndromes, ${ }^{3}$ with only one case reported. ${ }^{4}$

We hypothesize that a parainfectious anti-MOG antibody response combined with endothelial dysfunction to cause this unique clinicoradiologic CNS presentation. Vascular complications are increasingly recognized in COVID-19. The angiotensin-converting enzyme 2 receptors targeted by SARS-CoV-2 are expressed by endothelial cells in multiple organs including the brain. ${ }^{5}$ Recent histopathology from patients with COVID-19 has demonstrated a lymphocytic endotheliitis in the lungs, heart, kidney, small intestine, and liver with evidence of infarction. ${ }^{6}$ The blood-brain barrier breakdown secondary to endotheliitis, as suggested by the linear and punctate enhancement, may have facilitated the entry of anti-MOG antibodies to initiate the disease process and resulted in the unusual clinical and radiologic picture. The enlarged perivascular spaces returned signal higher than the CSF on fluid-attenuated inversion recovery sequences, which may represent distension by leucocytes migrating across the cerebral endothelium before traversing the glia limitans. ${ }^{7}$ The twice negative CSF SARS-CoV-2 PCR supports the idea that the CNS pathology was not because of parenchymal infection. The response to IVMP and PLEX was striking and is in keeping with the hypothesis of an immune-mediated process.

\section{Study funding}

Medical Research Council (UK) —A. Varatharaj and I. Galea.

\section{Disclosure}

No relevant disclosures. Go to Neurology.org/NN for full disclosures. 


\section{Publication history}

Received by Neurology: Neuroimmunology \& Neuroinflammation May 20, 2020. Accepted in final form May 26, 2020.

Appendix Authors

\begin{tabular}{lll}
\hline Name & Location & Contribution \\
\hline $\begin{array}{l}\text { Ashwin } \\
\text { Pinto, DPhil, } \\
\text { FRCP }\end{array}$ & $\begin{array}{l}\text { Wessex Neurological } \\
\text { Centre, } \\
\text { Southampton, UK }\end{array}$ & $\begin{array}{l}\text { Design and conceptualized the } \\
\text { study, analyzed the data, and } \\
\text { drafted the manuscript for } \\
\text { intellectual content }\end{array}$ \\
\hline $\begin{array}{l}\text { Liam Carroll, } \\
\text { PhD, MRCP }\end{array}$ & $\begin{array}{l}\text { Wessex Neurological } \\
\text { Centre, }\end{array}$ & $\begin{array}{l}\text { Major role in the acquisition of } \\
\text { data }\end{array}$ \\
$\begin{array}{l}\text { Southampton, UK } \\
\text { Mijay Nar, }\end{array}$ & $\begin{array}{l}\text { Wessex Neurological } \\
\text { Centre, }\end{array}$ & $\begin{array}{l}\text { Major role in the acquisition of } \\
\text { data }\end{array}$ \\
$\begin{array}{l}\text { Southampton, UK } \\
\text { Aravinthan } \\
\text { Varatharaj, } \\
\text { MRCP }\end{array}$ & $\begin{array}{l}\text { University of } \\
\text { Southampton, UK }\end{array}$ & $\begin{array}{l}\text { Interpreted the data and revised } \\
\text { the manuscript for intellectual } \\
\text { content }\end{array}$ \\
\hline
\end{tabular}

Appendix (continued)

\begin{tabular}{lll}
\hline Name & Location & Contribution \\
\hline $\begin{array}{ll}\text { Ian Galea, } \\
\text { PhD, FRCP }\end{array}$ & $\begin{array}{l}\text { University of } \\
\text { Southampton, UK }\end{array}$ & $\begin{array}{l}\text { Interpreted the data and revised } \\
\text { the manuscript for intellectual } \\
\text { content }\end{array}$ \\
\hline
\end{tabular}

\section{References}

1. Vonck K, Garrez I, De Herdt V, et al. Neurological manifestations and neuro-invasive mechanisms of the severe acute respiratory syndrome coronavirus type 2. Eur J Neurol Epub 2020 May 16

2. Jurynczyk M, Messina S, Woodhall MR, et al. Clinical presentation and prognosis in MOG-antibody disease: a UK study. Brain 2017;140:3128-3138.

3. Denève $\mathrm{M}$, Biotti $\mathrm{D}$, Patsoura $\mathrm{S}$, et al. MRI features of demyelinating disease associated with anti-MOG antibodies in adults. J Neuroradiol 2019;46:312-318.

4. Komatsu T, Matsushima S, Kaneko K, Fukuda T. Perivascular enhancement in antiMOG antibody demyelinating disease of the CNS. J Neurol Neurosurg Psychiatry 2019;90:111-112.

5. Xia H, Lazartigues E. Angiotensin-converting enzyme 2 in the brain: properties and future directions. J Neurochem 2008;107:1482-1494.

6. Varga Z, Flammer AJ, Steiger P, et al. Endothelial cell infection and endotheliitis in COVID-19. Lancet 2020;395:1417-1418.

7. Bechmann I, Galea I, Perry VH. What is the blood-brain barrier (not)? Trends Immunol 2007;28:5-11. 


\section{Neurology ${ }^{\oplus}$ \\ Neuroimmunology \& Neuroinflammation}

CNS inflammatory vasculopathy with antimyelin oligodendrocyte glycoprotein antibodies in COVID-19

Ashwin A. Pinto, Liam S. Carroll, Vijay Nar, et al.

Neurol Neuroimmunol Neuroinflamm 2020;7;

DOI 10.1212/NXI.0000000000000813

This information is current as of June 10, 2020

Neurol Neuroimmunol Neuroinflamm is an official journal of the American Academy of Neurology.

Published since April 2014, it is an open-access, online-only, continuous publication journal. Copyright

Copyright $\odot 2020$ The Author(s). Published by Wolters Kluwer Health, Inc. on behalf of the American

Academy of Neurology.. All rights reserved. Online ISSN: 2332-7812.

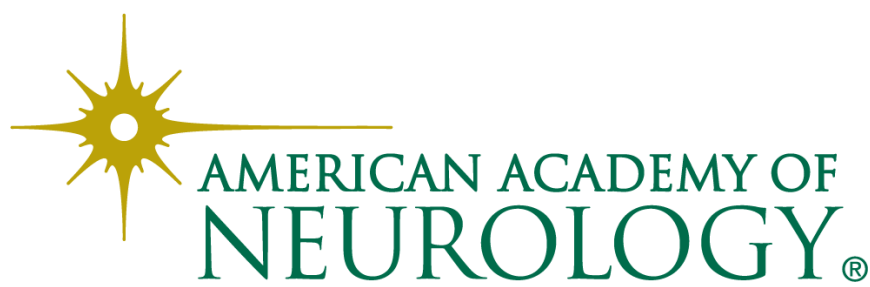




\section{Updated Information \& Services}

References

Citations

Subspecialty Collections

Permissions \& Licensing

Reprints including high resolution figures, can be found at: http://nn.neurology.org/content/7/5/e813.full.html

This article cites 6 articles, 1 of which you can access for free at: http://nn.neurology.org/content/7/5/e813.full.html\#\#ref-list-1

This article has been cited by 2 HighWire-hosted articles: http://nn.neurology.org/content/7/5/e813.full.html\#\#otherarticles

This article, along with others on similar topics, appears in the following collection(s):

\section{COVID-19}

http://nn.neurology.org//cgi/collection/covid_19

Encephalitis

http://nn.neurology.org//cgi/collection/encephalitis

MRI

http://nn.neurology.org//cgi/collection/mri

Other cerebrovascular disease/ Stroke

http://nn.neurology.org//cgi/collection/other_cerebrovascular_disease_ _stroke

Information about reproducing this article in parts (figures,tables) or in its entirety can be found online at:

http://nn.neurology.org/misc/about.xhtml\#permissions

Information about ordering reprints can be found online: http://nn.neurology.org/misc/addir.xhtml\#reprintsus

Neurol Neuroimmunol Neuroinflamm is an official journal of the American Academy of Neurology.

Published since April 2014, it is an open-access, online-only, continuous publication journal. Copyright

Copyright $\odot 2020$ The Author(s). Published by Wolters Kluwer Health, Inc. on behalf of the American Academy of Neurology.. All rights reserved. Online ISSN: 2332-7812.

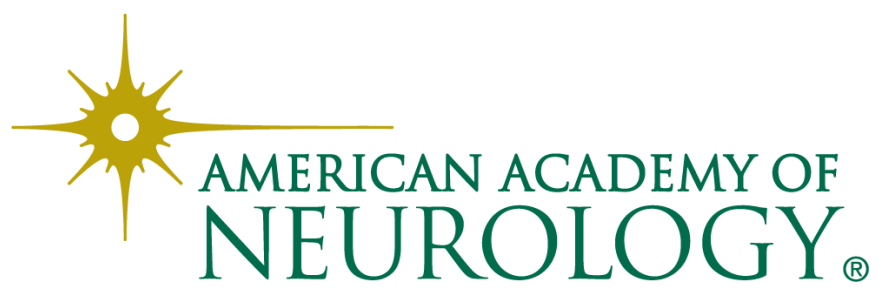

